\title{
SOCIALNO-GEOGRAFSKA PREOBRAZBA NASELBINSKIH STRUKTUR - KAKO USMERJATI RAZVOJ?
}

\author{
Marjan Ravbar \\ Geografski inštitut Antona Melika ZRC SAZU, Ljubljana, Gosposka I3, \\ SI-I000 Ljubljana, Slovenija \\ e-mail: marjan.ravbar@zrc-sazu.si
}

\section{Izvirni znanstveni članek}

COBISS 1.01

\section{Izvleček}

Rast naselij je tudi v Sloveniji že desetletja v pretežni meri povezana $\mathrm{s}$ širitvijo njihovih zunanjih meja izven historičnih in organskih pogojenih meja. V sodobnosti največjo dinamiko izkazujejo obmestna in tudi oddaljenejša podeželska naselja. Druga značilnost sodobne prostorske preobrazbe naselij pa je povezana s prevladujočo disperzno pozidavo pretežno prosto stoječih enostanovanjskih hiš, kar namesto že dolgo časa izraženih želja po decentralizirani koncentraciji bivanjskih območij, le-ta odstopa od političnih ciljev in v sorazmernem deležu povišuje stroške infrastrukturne opremljenosti.

Ključne besede: geografija Slovenije, socialna geografija, poselitev, urbanizacija, suburbanizacija, usmerjanje poselitve.

\section{SOCIAL-GEOGRAPHIC TRANSFORMATION OF SETTLEMENT STRUCTURES - HOW TO DIRECT THE DEVELOPMENT?}

\begin{abstract}
The growth of settlements in Slovenia has over the decades been associated with the growth of the outside borders of settlements beyond the historically and organically conditioned borders. Nowadays the greatest dynamics is seen within the suburban and rural settlements. The second characteristic of modern spatial settlement transformation is connected to the dominant and disperse build-up area with relatively free-standing one-apartment houses, which instead of longtime wishes for decentralistic concentration of residential areas, deviates from the political goals and in proportion raises the costs of infrastructure.
\end{abstract}

Key words: geography of Slovenia, social geography, settlement system, urbanization, suburbanization, settlement planning. 


\section{UVOD}

Rast naselij je tudi v Sloveniji že desetletja v pretežni meri povezana s širitvijo njihovih zunanjih meja izven historičnih in organskih pogojenih meja. V sodobnosti največje dinamike ne izkazujejo več mesta, marveč obmestna in tudi podeželska naselja, ki posledično sprožajo funkcionalno in socialno razslojevanje na področju bivanja, dela in prostega časa. Druga značilnost sodobne prostorske preobrazbe naselij pa je povezana s prevladujočo disperzno pozidavo kmetijskih zemljišč s pretežno prosto stoječimi enostanovanjskimi hišami in $\mathrm{s}$ pripadajočimi (poslovnimi in/ali proizvodnimi) gospodarskimi poslopji, kar namesto že dolgo časa izraženih želja po decentralizirani koncentraciji bivanjskih območij, le-ta odstopa od političnih ciljev (SPRS, 2004) in v sorazmernem deležu povišuje stroške infrastrukturne opremljenosti stavbnih zemljišč. Ključne značilnosti so povezane s spremenjenimi okvirnimi ekonomskimi pogoji globalizacije ter posledično $\mathrm{z}$ naraščanjem mobilnosti aktivnega prebivalstva s pomočjo osebnih prevoznih sredstev s katerimi ljudje dnevno potujejo na vedno daljše razdalje. Opisane težnje so najintenzivnejše v osrednji Sloveniji ter v vedno obsežnejšem zaledju vseh večjih mest, ob pogoju ugodne (cestno) prometne dostopnosti.

Preobrazba naselbinskih struktur je priložnost za nadaljnji razvoj metodoloških pristopov v socialni geografiji. Kljub temu da gre večinoma za procese, ki se v pokrajinskih strukturah postopno oblikujejo (razvijajo) skozi daljša časovna obdobja, jih praviloma interpretiramo šele ob aktualnih prilikah, ko se pričnejo družbeni in prostorski problemi zaostrovati. Preobrazbi sledimo tako na ekonomsko-, kot tudi na socialno-geografskem področju. Okvirno, dve desetletji trajajoči suburbanizacijski procesi zaradi spreminjajočih se družbenih (in predvsem ekonomskih) zakonitosti skozi procese zorenja dobivajo novo kvaliteto, ki jo v urbano geografskih raziskavah predstavljajo mestne regije, somestja v povezavi z oblikovanjem tim. "postsuburbije« (Ravbar, 1992). Preobrazba rabe površin ima v njih svoj vsebinski odsev v spremenjenih fiziognomskih in funkcijskih strukturah, ki zaradi medsebojne povezanosti mest z obmestji daje tem območjem povsem spremenjeno perspektivo pri oblikovanju omrežja urbanih sistemov in njihovih funkcij.

\section{CILJ}

Pričujoči prispevek bo poskusil odgovoriti na nekatere sodobne izzive v naselbinskem razvoju. Stremljenja temelje na pregledni analizi strukturnih sprememb in razvojnih težnjah v naselbinskem sistemu, ki so se zgodila v desetletju ob prelomu stoletja. Poleg ocene in vrednotenja strukturnih naselbinskih teženj, ki so posledica sodobnih družbeno ekonomskih sprememb, bomo posebno pozornost posvetili še dvema pojavoma in sicer: socialno- in ekonomsko geografski razprostranjenosti suburbanizacije, ki se vse bolj širi proti podeželskim območjem in splošni oziroma napredujoči disperziji naselbinskega sistema ter $\mathrm{z}$ njimi povezanimi strukturnimi spremembami znotraj samega naselbinskega sistema.

Ključna razglabljanja pa so povezana z razčlenjevanjem pogojev in vrednotenjem vzrokov za nastanek pospešene preobrazbe. Pri vrednotenju razvojnih posledic prostorske disperzije poselitve se torej opiramo na proučevanje izbranih, po našem mnenju, ključnih pospeševalcev geografskih procesov, ki potekajo ali spontano ali pa kot posledica določenih politik, ki so tudi 
privedle do današnjega stanja, vključno s težnjami. To pa zahteva zlasti natančno opazovanje tistih razvojnih procesov, ki se odvijajo neorgansko in/ali v nasprotju z zastavljenimi cilji. Na tem mestu zlasti velja opozoriti, da je pomembna presoja, na kakšen način so bile težnje izzvane: ali z družbeno-ekonomskimi in socialnimi vzgibi, ali pa morda (tudi) s političnim ravnanjem.

Delovne hipoteze temelje na izboru naslednjih razvojnih vprašanj: Kako se (bo) spreminja(la) obmestna-podeželska kulturna pokrajina? Ali lahko predvidevamo, da se bodo ta območja v soodvisnosti od zaposlitvenih pogojev še naprej širila in da bo vse večji delež podeželja postajal sestavni del mestnih regij? Ali lahko še naprej pričakujemo pospešen razvoj poselitve v obmestjih in kako daleč od mestnih središč bo segal ta vpliv? Ter ali se bo nadaljeval proces preobrazbe kmetijskih zemljišč v stavbna zemljišča in kakšen bo gospodarsko - geografski naselbinski razvoj?

Odgovorina aktualna vprašanja nam bodo služili kot vodilo za oblikovanje kritičnih premis, ki jih sprožajo gospodarska in/ali družbeno politična ozadja z odsevnostjo v naselbinskem vzponu suburbaniziranih območij. Na podlagi empiričnih analiz bomo v zaključku z vidika naselbinske »obremenljivosti« mestnih regij oblikovali priporočila za ukrepanje s pomočjo možnega oblikovanja (oz. reformulacije) izhodišč načrtovanja prostorskih politik obmestij in podeželskih naselij:

- Suburbanizacija v obmestjih vzpodbuja pospešeno disperzijo naselbinskega razvoja, kajti obmestja so zaradi visoke stopnje centralizacije na trgu delovne sile v mestnih središčih podrejena posebnim vrstam naselbinskega razraščanja in $\mathrm{s}$ tem hitrim strukturnim spremembam.

- Spontana dekoncentracija naselbinskega razvoja in razseljevanje prebivalstva $\mathrm{z}$ naraščanjem družbene blaginje sprožata masiven porast prometnih tokov. Poleg tega so obmestja zaradi pretežno intraregionalnih prometnih tokov močno obremenjena, kar terja posebno strategijo razbremenjevanja. Neprestan razvojni pritisk na naselbinsko omrežje v obmestjih terja oblikovanje okolju prijazne strategije usmerjanja naselbinskih območij, $\mathrm{s}$ tem da je tudi v prihodnje pričakovati spreminjanje namenske rabe površin, ki se bo v bolj kot doslej usmerjalo v zgoščevanje že obstoječih naselbinskih enot. Varčnejši razvoj potovanj na delo je mogoče doseči tudi z napredujočimi procesi razvoja delovnih mest v obmestjih, doslednim uveljavljanjem in implementacijo sistema decentralizirane koncentracije (npr. s pomočjo »mešane rabe površin «) in s pričakovanim razvojem novih komunikacijskih tehnologij v suburbaniziranih območjih, ki sicer ne preprečujejo dekoncentracije, omogočajo pa optimalnejšo izrabo prometnih tokov (Ravbar, 2002).

\section{PREGLED STRUKTURNIH SPREMEMB IN TEŽENJ V NASELBINSKIH STRUKTURAH SLOVENIJE}

Za Slovenijo je od nekdaj značilna velika razpršenost naselij in nizka stopnja urbanizacije (Vrišer, 1969). Primerjalna analiza v zadnjih štirih desetletij je, ob splošnem povečanju števila prebivalstva za četrtino, pokazala, da je v prvem obdobju (do začetka devetdesetih let) urbanizacija naglo napredovala, saj je bila stopnja absolutne koncentracije prisotna še v več kot polovici slovenskih mest. Po tem obdobju pa se je prebivalstvena dinamika v mestih, $\mathrm{v}$ 
primerjavi s prejšnjim obdobjem že prepolovila na račun rasti v večini obmestij slovenskih mest (Ravbar, 1992). Izračuni za celotno obdobje izkazujejo najvišjo stopnjo rasti v neposrednih obmestjih slovenskih mest in intenzivno koncentracijo $\mathrm{v}$ središčih regionalnega pomena, okrog katerih se je v sedemdesetih letih prejšnjega stoletja oblikoval venec industrializiranih naselij, ki so se (praviloma) oblikovala iz središč lokalnega pomena (središčnih vasi). Razvojna dinamika naselbinskega razvoja je tu enkrat višja od republiških povprečkov (gl. preglednico št. 1. ter grafikon št. 1). $\mathrm{V}$ dobri polovici preostalih (pretežno) podeželskih naselij pa se je število prebivalstva v tem obdobju v povprečju zmanjšalo za osmino. Geografska razprostranjenost območij nas opozarja, da so se najobsežnejša koncentracije oblikovala $\mathrm{v}$ obsežnejšem zaledju vseh večjih mest in zgostitvenih območij, zlasti v ravninskih delih ob največjih rekah (Sava, Drava, Savinja, Krka, Mura, Soča, ...) in ob obalnem pasu, ob pogoju ugodne (cestno) prometne dostopnosti. Dolgotrajno upadanje pa beležimo na pretežnem delu alpskega predgorja, na obsežnem Dinarsko-kraškem območju ter v veliki meri tudi preostalih (hribovitih in gričevnatih) delih Dolenjske, Posavja, Štajerske in Pomurja.

Preglednica 1: Spremembe v številu prebivalcev po naselbinskih tipih med leti 1961 in 2002 v Sloveniji

Table 1: The changes of the number of inhabitants according to settlement types in Slovenia between the years 1961-2002

\begin{tabular}{|l|r|r|r|r|r|r|r|}
\hline \multirow{2}{*}{ Tipi naselbinskih območij } & \multicolumn{3}{|c|}{ Prebivalstvo } & Spremembe v abs. št. & \multicolumn{2}{c|}{ Spremembe v \% } \\
\hline & 1961 & 1991 & 2002 & $2002 / 61$ & $2002 / 91$ & $2002 / 61$ & $2002 / 91$ \\
\hline Mesta & 478547 & 775183 & 754016 & +275469 & -21167 & $+57,6$ & $-\mathbf{2 , 7}$ \\
\hline $\begin{array}{l}\text { Ožja suburbanizirana } \\
\text { obmestja }\end{array}$ & 113786 & 178778 & 186663 & +72877 & +7885 & $+64,0$ & $+4,4$ \\
\hline Širša obmestja & 177503 & 216858 & 223073 & +45570 & +6215 & $+25,7$ & $+2,9$ \\
\hline Industrializirana naselja & 180526 & 254427 & 259039 & +78513 & +4612 & $+43,5$ & $+1,8$ \\
\hline Podeželska naselja & 641814 & 546708 & 555938 & -85876 & +9230 & $-\mathbf{1 3 , 4}$ & $+1,7$ \\
\hline Slovenija & 1592176 & 1971954 & 1978729 & +386553 & +6775 & $+24,3$ & $+0,3$ \\
\hline
\end{tabular}

Vir: SURS, lastni izračuni.

Tudi $\mathrm{v}$ poosamosvojitvenem obdobju se ob splošni stagnaciji prebivalstva napredujoči razvoj (post)urbanih struktur na ravninskih območjih, usmerjen iz mest in (tudi že) najožjih suburbaniziranih območij proti širšim obmestjem (in tudi podeželju) samo še nadaljuje ter na ta način nakazuje razvojno pot naselbinskega razvoja $\mathrm{v}$ gospodarsko in socialno se razvijajočih območjih na temeljih ekonomskih in strukturnih sprememb. Razlika je le v tem, da je razlog socialno-geografske preobrazbe urbaniziranih območij vse manj odvisen od (zmanjšane) rodnosti prebivalstva, zato pa toliko bolj povezan s povečano selitveno mobilnostjo prebivalstva, saj večina slovenskih večjih mest $\mathrm{v}$ zadnjih petih letih ob prelomu stoletja izkazuje negativni selitveni saldo v skupni višini -17.141 prebivalcev ( $0,9 \%$ od skupnega števila prebivalcev). Med njimi na opazovanem obdobju prednjačijo največja mesta: Ljubljana (-8.024), Maribor (-3.361), somestje obalnih mest (-2.539), Jesenice (-1.540), Celje (-1.244), Ptuj (-991), .. 
Grafikon 1: Spremembe v številu prebivalcev po naselbinskih tipih med leti 1961 in 2002 v Sloveniji Graph 1: The changes of the number of inhabitants according to settlement types in Slovenia between the years 1961-2002

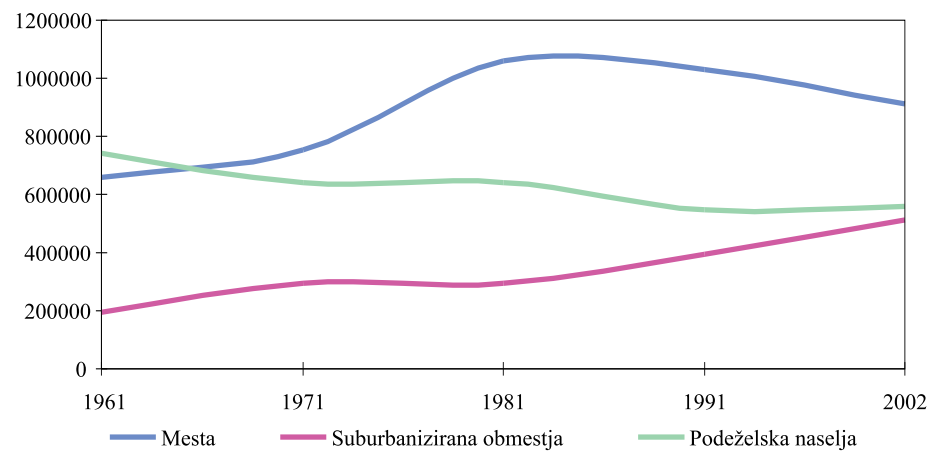

Zanimiv je tudi pregled razmerij med deleži števila prebivalcev, števila naselij in površjem, ki kažejo, da sta se v poldrugem desetletju oblikovali dve območji kjer približno dve petini prebivalstva živi v območjih priseljevanja. Težnje pa nakazujejo, da se delež površja in števila naselij s pozitivnim selitvenim saldom povečuje, medtem ko je delež števila prebivalcev s pozitivnim selitvenim saldom zaradi upadanja prebivalstva, povzročenega predvsem $\mathrm{z}$ negativnim selitvenim saldom $\mathrm{v}$ vseh večjim mestih zmanjšuje $\mathrm{v}$ obratnem sorazmerju (glej preglednico št. 2).

Preglednica 2: Razmerja med deleži števila prebivalcev, površjem in številom naselij s pozitivnim migracijskim saldom v treh časovnih prerezih v obdobju 1982-2000.

Table 2: The ratios between the shares of the number of inhabitants, the surface and the number of settlements with a positive migration balance in three time sections in the period 1982-2000.

\begin{tabular}{|l|r|r|r|}
\hline & $\mathbf{1 9 8 2 - 8 6}$ & $\mathbf{1 9 8 7 - 9 3}$ & $\mathbf{1 9 9 4 - 2 0 0 0}$ \\
\hline Delež površja s pozitivnim selitvenim saldom & 48 & 52 & 64 \\
\hline Delež prebivalstva s pozitivnim selitvenim saldom & $\mathbf{6 4}$ & $\mathbf{4 3}$ & $\mathbf{3 7}$ \\
\hline Delež naselij s pozitivnim selitvenim saldom & 41 & 49 & 55 \\
\hline
\end{tabular}

Vir: SURS, lastni izračuni.

V obdobju zadnje dekade na prelomu stoletja (1991-2002) se je število prebivalstva v mestih tako zmanjšalo v povprečju za $3 \%{ }^{1}$, v obmestjih pa poraslo za $5 \%$. V tem času je bilo v Sloveniji zgrajenih 90.852 stanovanj, od tega po ocenah okoli $3 / 4 \mathrm{~V}$ enodružinskih prosto stoječih hišah. Stanovanjska rast se povečuje $\mathrm{z}$ naraščanjem (neformalnega) števila gospodinjstev pretežno na račun zmanjševanja povprečnega števila članov na gospodinjstvo,

\footnotetext{
${ }^{1}$ Še posebej je padanje mestnega prebivalstva intenzivno v Zasavju, na Goriškem, v Pomurju in Savinjskem, kjer se je v povprečju zmanjšalo za več kot $5 \%$.
} 
čigar število upada že pol stoletja (gl. preglednico št. 3). Poslej velja, da se zaradi tehnoloških sprememb in preobrazbe gospodarske in družbene strukture tudi v Sloveniji poslavljamo od demografske rasti v mestih in stopamo v obdobje "urbanega razvoja brez rasti", ki jo v grobem označujeta prostorska širitev mestnih vplivov v obmestja ${ }^{2}$ in notranja preobrazba mest $^{3}$ (Ravbar, 2004). Statistični podatki še opozarjajo, da se je obseg pozidanih površin med 1993 in 2001 povečal za 18.431 ha $^{4}$. Nadpovprečne spremembe opazujemo zlasti na obrobjih mest, ne glede na njihovo velikost in položaj v hierarhični zasnovi urbanega omrežja in prav tako na podeželju. Tu so se zazidane površine povečale za 16367 ha kar je 87 \% od vseh na novo pozidanih površin. $Z$ obstoječimi podatkovnimi bazami je moč analizirati tudi razmerja med različnimi podskupinami pozidanih zemljišč. Tako npr. površine naselij predstavljajo 71 \% medtem, ko je preostalih 29 \% površin zasedajo različni infrastrukturni objekti in naprave med katerimi prevladuje cestno omrežje (gradnja avtocestnega prometnega križa). Porast poselitvenih površin ima nazorno »odslikavo« v znatnem zmanjšanju kmetijskih površin (več o tem v: Ravbar, 2006).

Preglednica 3: Razvoj nekaterih demografskih kazalnikov in poselitvenih površin v zadnjem desetletju $v$ Sloveniji

Table 3: Development of some demographic indicators and residential areas in Slovenia in the last decade

\begin{tabular}{|l|r|r|r|}
\hline & $\mathbf{1 9 9 1}$ & $\mathbf{2 0 0 2}$ & Indeks rasti \\
\hline Prebivalstvo & 1.913 .355 & 1.948 .250 & $102 \%$ \\
\hline Gospodinjstva & 632.278 & 688.733 & $109 \%$ \\
\hline Stanovanja & 684.279 & 775.131 & $113 \%$ \\
\hline Poseljene (pozidane) površine v ha & 60.357 & 78.788 & $131 \%$ \\
\hline Povprečno število preb/gospod & 3,03 & 2,83 & $93 \%$ \\
\hline Neto poselitvena gostota (pozidane površine/preb.) v ha & 229,3 & 237,6 & $104 \%$ \\
\hline
\end{tabular}

Vir: SURS in GURS

Spremembam v naselbinskem razvoju sledi tudi preobrazba v razvoju delovnih mest. Splošnem padcu števila delovnih mest po letu 1987 (ki je trajal do sredine devetdesetih let prejšnjega stoletja) je najprej sledila povečana stopnja brezposlenosti. V drugi polovici devetdesetih so se razmere na trgu delovne sile stabilizirale. Pač pa smo zaradi obsežnih družbenih in gospodarskih sprememb (globalizacija, liberalizacija trgovine, deregulacija finančnih trgov, nove komunikacijske tehnologije, ...) priča opaznim strukturnim spremembam

\footnotetext{
${ }^{2}$ Pojav je mogoče označiti tudi kot naraščajočo stihijsko suburbanizacijo.

${ }^{3}$ Ali tudi kot spreminjanje dohodkovno ekstenzivnejših rab v dohodkovno intenzivnejše.

${ }^{4}$ Povprečni indeks sprememb v osemletnem obdobju je $131 \%$, ali v 2.304 ha letno, oz. 6,3 ha/dan (!). Med statističnimi regijami so se stavbna zemljišča povečala za več kot 2000 ha v Osrednji Sloveniji, Podravju in Savinjskem. Nadpovprečno relativno stopnjo sprememb pa beležimo na Goriškem, Koroškem, Posavju, Zasavju, Dolenjskem in obalno-kraškem območju.

${ }^{5}$ Primerjalni podatki veljajo za obdobje med leti 1994 in 2001, Vir: SURS, medmrežje: http://www.stat.si/doc/vsebina/gis_podatki.doc
} 
v zaposlenosti aktivnega prebivalstva. Namesto prevlade sekundarnega sektorja v strukturi aktivnega prebivalstva, $\mathrm{v}$ zadnjih letih prevladuje delež terciarja in kvartarja oz. servisnih dejavnosti.

Za razvoj naselbinskega sistema so odločujočega pomena zlasti prerazporeditve delovnih mest, ki se postopoma prav tako razporejajo enakomerneje-izven tradicionalnih zaposlitvenih središč, saj ima vsaj eno delovno mesto že 4286 ali $70 \%$ slovenskih naselij ${ }^{6}$. To pomeni, da se je število naselij z najmanj enim delovnim mestom tudi v najmanjših - pretežno podeželskih naseljih v zadnjem desetletju povečalo za dve tretjini. Izračuni lokacijske divergence (več o tem v: Ravbar, 2002) na ravni lokalnih skupnosti sicer še vedno kažejo močno polarizacijo zaposlitvenih aktivnosti $v$ tistih mestih z nad 10.000 delovnimi mesti, $\mathrm{v}$ katerih je okvirno nekaj nad 70.000 več delovnih mest kot aktivnega prebivalstva in količnik lokacijske divergence za $13 \%$ presega število rezidenčnega aktivnega prebivalstva. Gre predvsem za zaposlitvena središča v največjih mestih, med katerimi izstopajo zlasti: Ljubljana, Maribor, Celje, Murska Sobota, Velenje, Novo mesto, Kranj, Ptuj, Nova Gorica, Koper, Domžale, Slovenj Gradec, Postojna, Sežana, Trbovlje in Ravne na Koroškem, kjer je skupaj več kot polovica delovnih mest v Sloveniji. Zaposlitvena središča z manj kot 10.000 delovnimi mesti imajo pa praviloma primanjkljaj med aktivnim prebivalstvom. Tako ima npr. le $15 \%$ lokalnih skupnosti pozitivno lokacijsko divergenco kar z drugimi besedami pomeni, da iz območja svoje rezidenčne lokalne skupnosti dnevno potuje na delo okoli dve tretjini vseh zaposlenih. Tretjina novonastalih občin ima na območju svoje lokalne skupnosti opazen primanjkljaj (v povprečju za več kot 500 delovnih mest), kar z drugimi besedami pomeni, da se iz teh občin v povprečju več kot tri četrtine aktivnega prebivalstva dnevno vozi na delo v zaposlitveno središče izven območja svoje matične lokalne skupnosti. Najvišjo negativno stopnjo lokacijske divergence in s tem najvišji primanjkljaj v številu delovnih mest $\mathrm{v}$ razmerju do aktivnega prebivalstva imajo občine v SV Sloveniji, med njimi posebej prednjačijo novoustanovljene občine v Slovenskih Goricah, na Dravskem polju, v Halozah in na Goričkem.

Vsa mestna naselja in po drugi vojni nastala industrializirana središča imajo še vedno pozitivno lokacijsko divergenco delovnih mest. Padec števila delovnih mest je v industrializiranih naseljih nižji od tistega v mestih in ta naselja so v zadnjem desetletju celo povečala svoj delež v skupnem številu delovnih mest, ki znaša okoli šestine. Njihov relativni delež pa se kljub temu postopno zmanjšuje na račun hitrejšega naraščanja delovnih mest v obmestjih. Obmestja imajo sicer še vedno negativno lokacijsko divergenco oz. približno tretjinski primanjkljaj delovnih mest $\mathrm{v}$ primerjavi s številom aktivnega prebivalstva, vendar se le-ta postopno zaradi nadpovprečne rasti zmanjšuje. Preobrat v naraščanju števila delovnih mest zaznavamo tudi na preostalem podeželju, kjer se je število v zadnjem obdobju povečalo za petino, čeprav je njihov delež v skupnem številu kljub temu še vedno zanemarljiv in znaša le okoli dvajsetine. Pogled na razpredelnico št 4 nas opozarja na sodobne odklone zadnjega desetletja med težnjami v razvoju delovnih mest, ki prav tako stremijo proti bolj decentralizirani koncentraciji števila delovnih mest, ki se oblikuje okrog »dnevnega dosega« do zaposlitvenega središča. Na ta način prispevajo k oblikovanju mestnih regij ter posledično vplivajo na spremembe v izrabi površin.

\footnotetext{
${ }^{6}$ Leta 1986 je bilo teh naselij le 2206 ali dobra tretjina, pred poldrugim desetletjem (1991) pa že 2902 ali $49 \%$.
} 
Preglednica 4: Spremembe v št. delovnih mest v obdobju 1993-2000 po značilnih skupinah naselij. Table 4: The changes of the number of workplaces in the period 1993-2000 according to characteristic groups of settlements

\begin{tabular}{|l|r|r|r|}
\hline Tipologija naselij & $\begin{array}{r}\text { Spremembe v št. } \\
\text { del. mest v \% }\end{array}$ & $\begin{array}{r}\text { Delež delovnih } \\
\text { mest 1993 }\end{array}$ & $\begin{array}{r}\text { Delež delovnih } \\
\text { mest 2000 }\end{array}$ \\
\hline Mesta & $\mathbf{8 1}$ & 68 & $\mathbf{6 4}$ \\
\hline Suburbanizirana obmestja & 109 & 6 & $\mathbf{7}$ \\
\hline Obmestna naselja & 102 & 6 & $\mathbf{7}$ \\
\hline Industrializirana naselja & $\mathbf{9 8}$ & 16 & 17 \\
\hline Podeželska območja & 119 & 4 & 5 \\
\hline Slovenija & 88 & 100 & 100 \\
\hline Vir: SURS, lastni izračuni. & Opomba: • pozitivne težnje & \multicolumn{3}{|c}{ •negativne težnje }
\end{tabular}

Grafikon 2: Spremembe v številu delovnih mest v ljubljanski mestni regiji po naselbinskih tipih med leti 1996 in 2002

Graph 2: The changes of the number of workplaces in the Ljubljana city region according to settlement types between the years 1996 and 2002

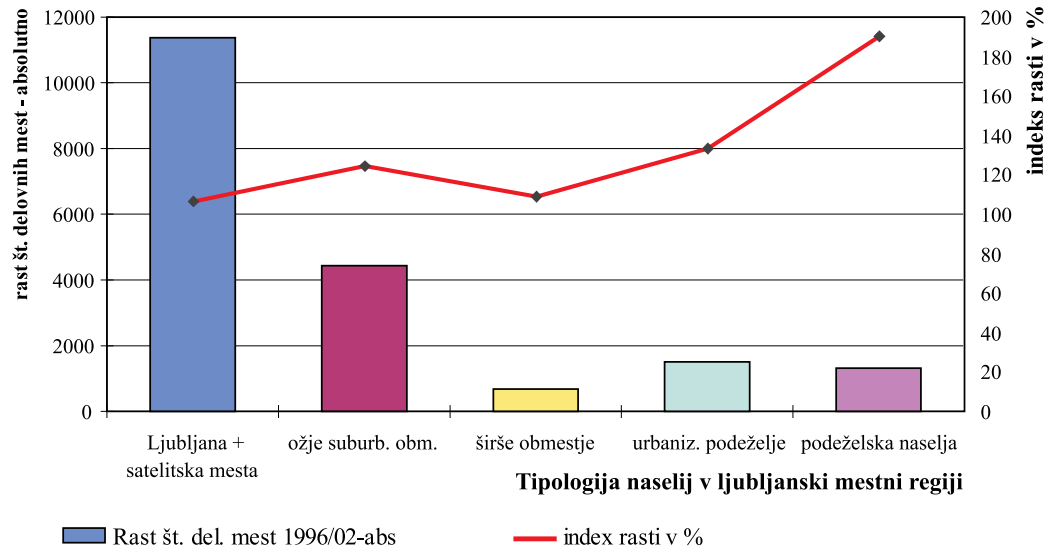

Gornjo trditev na empirični ravni potrjuje tudi spodnji grafični prikaz sodobnih sprememb v razvoju števila delovnih mest v ljubljanski mestni regiji, ki izpričuje, da gre po absolutnih številkah še vedno za koncentracijo v Ljubljani in satelitskih mestih. Delež delovnih mest v mestih pa se je na prelomu stoletja kljub temu znižal na račun pospešene relativne rasti v vseh ostalih naselbinskih tipih (gl. grafikon št. 2).

Naslednji, prav tako pomemben dejavnik strukturne preobrazbe $\mathrm{v}$ naselbinskem sistemu je povezan z izobrazbeno ravnijo prebivalstva. Razporeditev temelji na primerjavi medsebojnih strukturnih razmerij med tremi glavnimi skupinami dosežene najvišje stopnje izobrazbe in sicer: med dokončano osnovno, srednjo ter višje- oz. visokošolsko izobrazbo za vsako lokalno skupnost posebej. Primerjave prav tako kažejo na nadpovprečno koncentracijo 
bolj izobraženih prebivalstvenih skupin $\mathrm{v}$ okoljih $\mathrm{z}$ višjo stopnjo urbanizacije. Izrazito nadpovprečna raven izobrazbe je na Gorenjskem ter v obmestnih lokalnih skupnostih vseh večjih mest. Deleži prebivalcev z visoko in višjo izobrazbo so v mestih in obmestnih lokalnih skupnostih tri do sedemkrat višji od tistih v podeželskih občinah (gl. karto št. 1).

Karta 1: Tipološka členitev izobrazbene ravni prebivalstva.

Map 1: A typological division of educational level of population

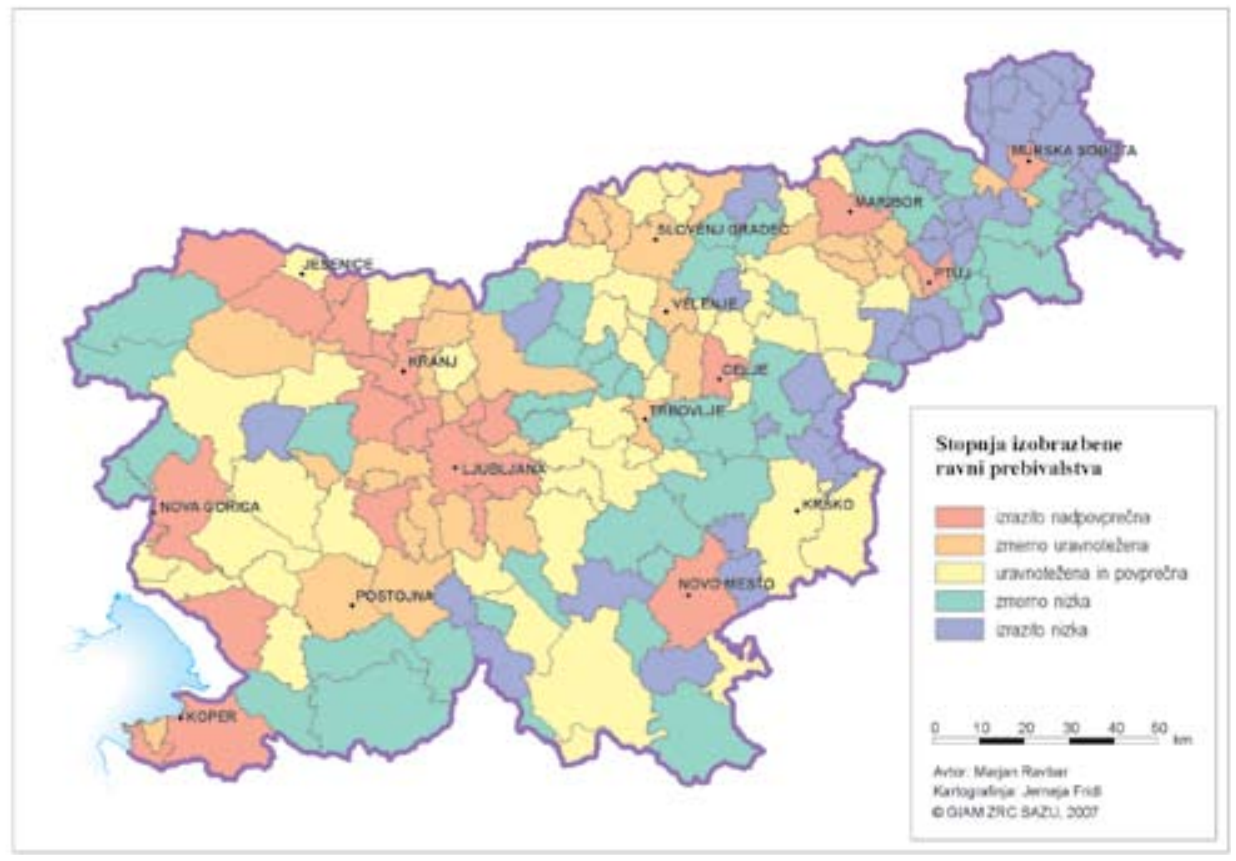

(vir: SURS, popis 2002)

Ključno vlogo pri preobrazbi sodobnega naselbinskega sistema, predvsem suburbanizacijskih procesov pa ima brez dvoma infrastrukturna povezanost, pri čemer igra odločujočo vlogo gostota cestno-prometnega omrežja. Slovenijo medsebojno povezuje $37.878 \mathrm{~km}$ cest $^{7}$, od tega jih ima status državnih (pomembnejših) cest $5.879 \mathrm{~km}$, preostalih $84 \%$ cest pa ima značaj lokalnih cest in/ali javnih poti. Gostota cestnega omrežja je $1,87 \mathrm{~km} / \mathrm{km}^{2}$ in nanjo je v povprečju navezanih 54 prebivalcev. Izrazito nadpovprečna raven gostote je na območju ljubljanske mestne regije, na Gorenjskem, Savinjske doline, Dravskega polja, spodnje Vipavske doline ter še v preostalih mestnih in obmestnih lokalnih skupnostih vseh večjih aglomeracij.

7 Vir: Direkcija RS za ceste, 2007 
Karta 2: Gostota cestnega omrežja v Sloveniji

Map 2: The density of road network in Slovenia

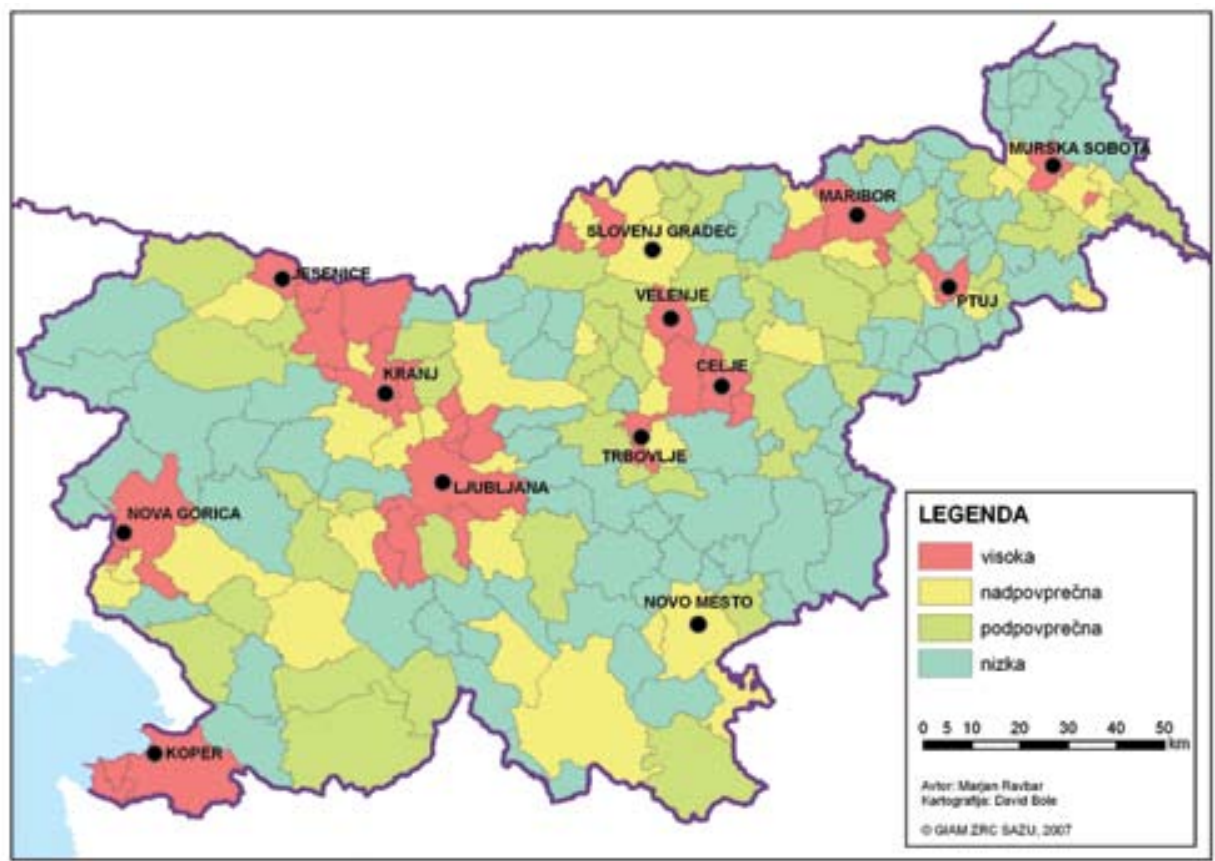

Vir: Ministrstvo za finance, Direkcija za ceste RS, 2006

Slovenija tudi s pomočjo tega kazalnika izkazuje jasno zasnovo razpršene - ploskovne in koridorske poselitve na obsežnih obmestjih v širokem tamponskem območju ob največjih urbanih središčih. Gostota poseljenosti v urbaniziranih območjih, kot eno izmed meril učinkovitosti infrastrukturne opremljenosti pa se na drugi strani že od konca devetdesetih let prejšnjega stoletja znižuje. Vzroki so v ugodnostih, ki jih ponujata množična motorizacija in državna usmeritev, ki s posodabljanjem cestnega omrežja omogoča, da povpraševalci po novih stavbnih zemljiščih iščejo možnosti izven ureditvenih območij mest. Pospešeno obremenjevanje poselitvenih površin s prometnicami povečuje obremenjenost urbaniziranega okolja in jo je poleg tega izjemno težko načrtovati ter kar je še težje, zoper nezaželene učinke ukrepati. Ob pretežni stagnaciji števila prebivalcev v zadnjem desetletju in močnem naraščanju naselbinskih površin pa se tudi gostota tehnične (cestno - prometne) infrastrukture na prebivalca nenehno povečuje in s tem, zlasti v obmestjih, sproža še dodatne obremenitve ter hkrati opozarja na veliko breme za prihodnje generacije. Dolgotrajnejše zanemarjanje tega problema prej ali slej privede do nujnih sanacij in s tem znatno povečanje (nenačrtovanih) finančnih sredstev. 


\section{SOCIALNO GEOGRAFSKE POSLEDICE PREOBRAZBE NASELBINSKIH STRUKTUR}

Intenzivna preobrazba obmestnega naselbinskega sistema je v prvi vrsti odsev družbenih preferenc, ki sta posledici ekonomsko- in socialno-geografskih vzgibov. Ekonomsko geografske spodbude označujeta zlasti globalizacija in prehod v informacijsko družbo. Ujema se še s postfordizmom, z oblikovanjem novih mrežnih podjetniških struktur in z nadaljevanjem nazadovanja ekonomskega pomena kmetijstva. Socialno geografsko preobrazbo pa spodbujajo spremembe v načinu življenja ter porast mobilnosti, povezana zmnožično motorizacijo. Procese še dodatno pospešujejo relativno cenene možnosti za raznolike graditeljske aktivnosti in s tem povzročajo dodatne pritiske na pretežno podeželske - kmetijske površine, ki so pogosto tudi v veliki meri odsev nezdravih razmer na trgu nepremičnin, npr. pri zemljiški politiki ${ }^{8}$ ali pa kot odziv na problematično načrtovanje razvojnih zamisli in presoj. Lokalne skupnosti običajno s pripravljanjem izvedbenih prostorskih dokumentov dajejo prednost nekmetijski rabi površin pred varstvom in ohranjanjem podeželske pokrajine, bodisi za bivanje ali za ustvarjanje novih delovnih mest v nekmetijskih dejavnostih.

Nosilci preobrazbe so praviloma individualni investitorji, ki sprožajo nove mrežne strukture, raznolikost $\mathrm{v}$ ekonomskih aktivnostih in $\mathrm{z}$ drobno dekoncentracijo ustvarjajo »fragmentacijo« obmestne in tudi podeželske pokrajine. Vsak izmed naštetih družbeno-ekonomskih procesov na svoj način prispeva k razmahu suburbanizacije, zmanjševanju nasprotij med mesti in podeželjem, višji stopnji avtonomnosti obmestij ampak tudi dodatnemu obremenjevanju geografskega okolja. Na širjenje suburbanizacije vplivajo številni dejavniki. Socialno geografske razsežnosti razrasta poselitvenih površin imajo svoj izvor v bolj ali manj racionalnem ravnanju gospodinjstev in gospodarskih akterjev pri vedenjskem obnašanju izbora novih lokacij stanovanj ali gospodarskih objektov. V vsakem primeru gre za večdimenzionalno širjenje naselbinskega razvoja $\mathrm{v}$ obmestja: povečuje se gostota prebivalstva, poleg tega se $\mathrm{z}$ razvojem proizvodnih in služnostnih delovnih mest intenzivira število (cirkulacija) dnevnih migrantov. Suburbanizacijo na svojstven način pospešuje tudi javni sektor s posodabljanjem javne infrastrukture, ki je ključnega pomena pri investicijskih odločitvah. Vse kaže, da ima pri tem odločujočo vlogo posodabljanje predvsem cestnega omrežja. Vzroki so prav gotovo v ugodnostih, ki jih ponujata množična motorizacija in državna usmeritev, ki s posodabljanjem cestnega omrežja omogoča, da povpraševalci po novih stavbnih zemljiščih iščejo možnosti izven ureditvenih območij mest. Pospeševanje npr. industrijskih (tehnoloških) parkov, nakupovalnih središč (bodisi na mestnem obrobju ali pa tudi $\mathrm{v}$ podeželskih območjih) ustvarja nova delovna mesta. To pa je hkrati že znamenje atraktivnosti določenega območja, ki suburbanizacijo samo še dodatno pospešuje.

\footnotetext{
8 Razseljevanje je v veliki meri odsev zemljiške politike, ko lastniki zemljišč na podeželju prodajajo kmetijska in gozdna zemljišča najboljšemu ponudniku.
} 
Preglednica 5: Preobrazba sodobnih prostorskih naselbinskih struktur

Table 5: The transformation of modern spatial settlement structures

\begin{tabular}{|c|c|c|}
\hline \multicolumn{3}{|c|}{ Preobrazba sodobnih prostorskih naselbinskih struktur } \\
\hline Spodbude, pogoji, ... & $\begin{array}{l}\text { Ekonomsko geografska } \\
\text { preobrazba: } \\
\text { - } \quad \text { Prost pretok blaga, kapitala, } \\
\text { dela in znanja, } \\
\text { - } \quad \text { Fleksibilna specializacija, } \\
\text { - } \quad \text { Globalizacija družbe, } \\
\text { - } \quad \text { Informacijska družba }\end{array}$ & $\begin{array}{l}\text { Socialno geografska preobrazba: } \\
\text { - } \quad \text { spremembe v načinu življenja } \\
\text { in bivanja } \\
\text { - } \quad \text { množična motorizacija } \\
\text { - } \quad \text { porast mobilnosti } \\
\text { - } \quad \text { nove mrežne strukture }\end{array}$ \\
\hline $\begin{array}{l}\text { Akterji-dejavniki } \\
\text { preobrazbe }\end{array}$ & \multicolumn{2}{|c|}{$\begin{array}{l}\text { - } \quad \text { nova servisno-proizvodna območja, nakupovalna središča ... } \\
\text { - } \quad \text { nova delovna mesta, ... } \\
\text { individualni investitorji, kot posledica odsotnosti primernega } \\
\text { načrtovanja }\end{array}$} \\
\hline $\begin{array}{l}\text { Rezultati } \\
\text { Ubikviteta lokacijskih } \\
\text { faktorjev }\end{array}$ & $\begin{array}{l}\text { - Polarizacija in fragmentacija } \\
\text { obmestne in podeželske } \\
\text { pokrajine, } \\
\text { - Zmanjševanje nasprotij } \\
\text { med mesti in podeželjem, } \\
\text { - Višja stopnja avtonomnosti } \\
\text { obmestij } \\
\text { - } \quad \text { Nove mrežne strukture } \\
\text { v funkciji poselitve in } \\
\text { produkcije }\end{array}$ & $\begin{array}{l}\text { - Povečevanje raznolikosti } \\
\text { v ekonomskih aktivnostih: } \\
\text { "Mešana raba površin” } \\
\text { - Multifunkcionalnost - drobna } \\
\text { dekoncentracija, } \\
\text { - Razrast služnostnih in } \\
\text { proizvodnih dejavnosti v } \\
\text { obmestjih (tarciarizacija), } \\
\text { - Dodatno obremenjevanje okolja... }\end{array}$ \\
\hline $\begin{array}{l}\text { Preobrazba funkcij v } \\
\text { urbanizirani pokrajini }\end{array}$ & \multicolumn{2}{|c|}{$\begin{array}{l}\text { Relativno zmanjševanje pomena mestnih središč, spremembe v funkcijah } \\
\text { na podeželju kot komplementarnem območju mestom } \\
=\text { suburbanizacija ("ne urbano in ne podeželsko") }\end{array}$} \\
\hline
\end{tabular}

K suburbaniziranim obmestjem prištevamo tista območja $\mathrm{v}$ vplivnem območju mestnih regij, kjer spekter in število ekonomskih dejavnosti ter prebivalcev izven tradicionalnih mestnih središč narašča. Izhajajoč iz doslej opravljenih raziskav (Ravbar, 1992 in 1997) pri slovenski »različici« suburbanizacije razločujemo suburbanizacijo v najbližjih ter širših obmestjih in še ubikvitarno (vsesplošno) suburbanizacijo. Na ta način so se tudi do nedavna podeželska območja temeljito preobrazila.

Obmestja so v mnogoterih pogledih funkcijsko povezana z bližnjimi mesti ter skupaj z njimi oblikujejo mestno pokrajino. Po svojem značaju predstavljajo zapleten in kompleksen družbeno ekonomski in socialno geografski pojav, ki je posledica tako polpreteklih (deagrarizacija, industrializacija, urbanizacija, migracije, preslojevanje prebivalstva, ...) in sodobnih družbenih procesov, povezanih $\mathrm{z}$ razrastom neagrarnih dejavnosti $\mathrm{v}$ podeželski pokrajini. Kot celota so sicer še vedno samobitna območja, istočasno pa jih je nasproti mestnim središčem razumeti kot komplementarno območje. Najprej gre za součinkovanje socialno ekonomskih funkcij, ki jih s pomočjo partnerskih razmerij na specifičen način izkorišča prebivalstvo s svojimi aktivnostmi. V sodobnosti si mesta in obmestja več medsebojno ne »konkurirata«, ampak se z intenzivnim spletom povezav medsebojno funkcijsko dopolnjujeta. 
Splošen pojav obmestij je povezan z vse gostejšo poseljenostjo območij in tudi s postopno razpršitvijo ekonomskih aktivnosti iz mestnih središč.

Obmestja torej v prvi vrsti pomenijo razširitev človekovih aktivnosti iz mest proti podeželju. Predstavljajo najvitalnejše življenjsko in hkrati gospodarsko območje za bivanje in delo. Prav zato jih spremljajo intenzivni in preobražajoči se procesi v demografski, zaposlitveni in socialni sestavi prebivalstva, s čimer se spreminjajo ekonomska, funkcijska in fiziognomska struktura široke (ob)mestne pokrajine. Tu ob porastu stanovanjskih površin ne srečujemo več samo kmetijskih obratov oz. klasičnih podeželskih struktur (kjer tudi proizvodnja hrane ni zanemarljiva), ampak v vse večjem obsegu tudi drobna in srednje velika podjetja industrijsko - proizvodnega in služnostnega sektorja ter široko ponudbo trgovskih dejavnosti. Nadalje, obmestja izpolnjujejo zelo pomembno funkcijo povezano z naraščajočim pomenom izkoriščanja rekreacijskih potencialov na podeželju, prostim časom in turizmom. In končno, obmestja imajo osrednji pomen pri ohranjanju naravnih življenjskih funkcij, povezanih z biotsko pestrostjo pokrajine. Te zadnje funkcije so z gospodarskega vidika komaj donosne, toda z vidika trajnostnega razvoja nepogrešljive.

Suburbanizacija, kot poglavitno razvojno gibalo preobrazbe obmestij je v Sloveniji prisotna že dobri dve desetletji. Dosedanje analize (Ravbar, 1992, 2002 in 2005) so pokazale, da s pomočjo proučevanja pojavnih geografskih značilnosti razlikujemo najmanj dve razvojni stopnji in sicer: »stanovanjsko« (ali tudi »demografsko«) suburbanizacijo ter suburbanizacijo proizvodnih in služnostnih dejavnostih. Demografska rast obmestij in razpršitev urbanizacije ob prometnicah z ugodno dostopnostjo in objekti nižje gostote na urbanih obrobjih ob obstoječih podeželskih naseljih označuje začetek suburbanizacije. Njej pa je po razpadu socialističnega gospodarskega sistema kmalu sledil skoraj identičen prostorski razmah ali ekspanzija gradbenih površin za proizvodne, trgovinske in služnostne dejavnosti, oz tim. »industrijska« suburbanizacija. Z geografskega vidika je pomembno, da ob prelomu stoletja razvoj delovnih mest in prostorska preobrazba proizvodno servisnih dejavnosti v obmestjih zadnjem obdobju že potekajo s podobno intenzivnostjo kot demografsko-naselbinski razvoj (Ravbar, 2002). To pomeni, da smo stopili v obdobje zrelejše faze suburbanizacije, ko so meje in pojavne oblike med različnimi tipi suburbanizacije zaradi medsebojne prepletenosti običajno zabrisane.

Stanovanjska suburbanizacija: izseljevanje prebivalstva in gospodinjstev iz mest $\mathrm{z}$ ciljem uresničitve življenjskih sanj z gradnjo individualne stanovanjske hiše $\mathrm{v}$ zelenju je uveljavljena razlaga za klasični vzorec suburbanizacije v Evropi, Severni Ameriki in tudi v Sloveniji. Razsežnosti suburbanizacije je moč razložiti še z naraščanjem družbene blaginje, ki je znatno pripomogla k izboljševanju kvalitete bivanja, kakršnih večstanovanjska blokovna gradnja v mestih in urbanih zgostitvah ni mogla zagotoviti. Individualne aspiracije po dodatnih stanovanjskih površinah pa so sčasoma nenehno naraščale, kar je v Sloveniji koncem osemdesetih let preteklega stoletja generiralo suburbanizacijo (Kaltenbrunner, 2003), ki je gonilna sila pritiskov na spremembe (in potratnost) v strukturi namenske rabe površin tudi na prelomu stoletja. Ker so novogradnje klasičnih prostostoječih enostanovanjskih objektov (praviloma) možne samo na še prostih zemljiščih v bolj ali manj oddaljenih mestnih obrobjih, je mogoče opazovati specifično povezanost med socialnim okoljem in lokacijskimi dejavniki, ki odločajo o izbiri (novega) kraja bivanja: bodisi da gre za lastništvo nepremičnin 
(z nakupom ali dedovanjem), ali višje stanovanjske standarde, ali občutek večje varnosti, spremembe v načinih socialne komunikacije prebivalstva, infrastrukturno opremljenost, itd. (Matthiesen, 2002).

Za razliko od klasičnih pogledov na razvoj suburbanizacije ob prelomu stoletja na račun priseljevanja v vedno bolj oddaljena območja od mestnih središč že zaznavamo znaten porast rabe površin za prosto stoječe stanovanjske objekte tudi v tim. »eksurbanih « območjih (Ravbar, 2002). Po nekaterih ocenah je na področju trga nepremičnin povpraševanje po stanovanjskih površinah prav v območjih s časovno izohrono nad $30 \mathrm{~min}$. od poglavitnega zaposlitvenega središča porast v dvakrat intenzivnejši kot v bližnjih obmestjih (Bergmann, Dosch, 2004) kar se odslikava tudi v naraščanju obremenitev prometnih tokov iz oddaljenejših podeželskih območij proti mestnim središčem. Poglavitni nosilci stanovanjske suburbanizacije so praviloma zaposlene mlade družine (35 do 40 let) s srednjimi (ali višjimi) dohodki in z enim do največ treh otrok. Po svoje si te družine oblikujejo poseben življenjski stil, ki je skoraj klišejsko odvisen od osebnega potovanja na delo. V odvisnosti od dostopnosti in pripadajoče naselbinske infrastrukturne opremljenosti se hitro povečujejo gospodinjstva z dvemi ali tremi osebnimi avtomobili na gospodinjstvo (Herfert 1998).

Suburbanizacija proizvodnih in trgovinskih dejavnosti: začetke tim. industrijske suburbanizacije so napovedovali že »dislocirani« obrati matičnih industrijskih panog v sedemdesetih letih prejšnjega stoletja, ko so industrijske obrate iz različnih nagibov selili na podeželska območja (ustrezne površine, ustvarjanje novih delovnih mest in s tem pospeševanje regionalnega razvoja, ...).

$\mathrm{Z}$ naraščajočo dinamiko konkurenčnosti in tehnoloških sprememb se spreminjajo tudi načini ravnanja $\mathrm{v}$ obmestjih, ki imajo specifične prostorske predpostavke in implikacije. Strukturne spremembe v proizvodnem sektorju in služnostnih dejavnostih so osrednjega pomena pri prostorski organizaciji dejavnosti v Sloveniji v zadnjem desetletju. V ekonomskem pogledu predstavljajo gonilno silo decentralizacijskih procesov. Vzvodi, ki označujejo hkrati razpršitev in tudi medsebojno povezanost so racionalizacija blagovnega poslovanja, povečevanje konkurenčnosti v zaledju, internacionalizacija podjetništva, uporaba novih tehnologij. Dinamična konkurenčnost, koncentracijske tendence določajo način ravnanja in »filializacijo«, razpršitev produkcijskih enot v mreže in posledično v dekoncentracijo. Sodobna raznolikost produktivnosti omogoča različne oblike produkcijskih oblik. Sem sodijo tudi stanovanjska območja, kamor so se skupaj s svojo obrtno delavnico preselili posamezni obrtniki. Praviloma gre tudi za mešane proizvodno-stanovanjske dejavnosti, od koder so se gospodinjstva odselila iz mest.

Pri strukturnih spremembah v trgovini so lokacije na obrobju v urbaniziranih območij in spremenjene nakupovalne navade medsebojno povezane in $\mathrm{v}$ zadnjih dveh desetletjih igrajo osrednjo vlogo tudi pri preobrazbi naselij. Lokacijske strukturne spremembe imajo izhodišče $\mathrm{v}$ spremenjenih marketinških strategijah na strani ponudbe, ki so korenito spremenile nakupovalne navade med potrošniki. Vzporedno z razširitvijo prodajnih površin in decentralizacijo nakupovalnih središč pa hkrati opažamo prostorsko koncentracijo ponudbe $\mathrm{v}$ velikih nakupovalnih kompleksih, ki sicer niso v skladu izkoriščanjem prednosti stopnjevitih ekonomskih možnosti, ujemajo pa se z željami potrošnikov po široki ponudbi nakupovalnih možnosti na enem mestu in »doživljajskih« možnosti nakupovanja. 


\section{KAKO USMERJATI NASELBINSKI RAZVOJ?}

Tudi v Sloveniji - tako kot v pretežnem delu Evrope - že desetletja opazujemo nenehno povečevanje pozidanih površinnaračunzmanjševanja deležev pridrugih(pretežnoobdelovalnih) zemljiških kategorijah. Poselitveni razvoj je v prevladujoči meri povezan s spremenjenimi oblikami načina življenjskih navad med slovenskim prebivalstvom. Razraščanje poselitvenih površin je v poglavitni meri odsev naraščanja stopnje družbene blaginje in z njimi povezanih tehnološko-ekonomskih ter družbenih sprememb. Slovenija se poleg tega nahaja - tako kot številne evropske države - pred usodnimi demografskimi in strukturnimi spremembami, ki jih spremljata še socialna in gospodarska polarizacija. Kot posledica globalne konkurenčnosti na pomenu pridobivajo območja $\mathrm{z}$ ugodnimi lokacijskimi pogoji kjer so napetosti med širjenjem urbanizacije in med že tako pičlimi obdelovalnimi površinami največje. Usmerjanje naselbinskega razvoja potemtakem ni povezano le s prostorsko (ekološkimi) instrumenti, marveč tudi z ekonomskimi in socialnimi kazalniki. Tudi investicije v naselbinski razvoj in pripadajočo infrastrukturo doslej še niso bile ustrezno ovrednotene.

(Ne)racionalna raba organizacije naselbinskega sistema $\mathrm{v}$ pokrajini je eden izmed ključnih kazalnikov za uravnotežen prostorski razvoj in osrednji problem urejanja prostora. Prizadevanja za dolgoročnejše zmanjševanje pritiskov za pozidavanje različnih zemljiških kategorij segajo v Sloveniji že v začetek sedemdesetih let dvajsetega stoletja ${ }^{9}$. Prve zakonske podlage pa so nato povezane $\mathrm{z}$ varovanjem kmetijskih zemljišč iz začetka osemdesetih let. Pozneje je bilo na državni ravni uveljavljenih še vrsta prostorskih dokumentov ${ }^{10}$, čigar pomemben cilj je bil tudi vzpostavitev pogojev za racionalni poselitveni sistem.

Kljub prizadevanjem za vzpostavitev trajnostnega naselbinskega razvoja (SPRS, 2004 in SRS, 2005), se dekoncentacijske težnje naselbinskega sistema nadaljujejo. Pogojenost razvoja naselij od naravno geografskih faktorjev se še nadalje zmanjšuje na račun infrastukturno pogojenih činiteljev, ki utrjujejo pritiske na kmetijske površine ob komunikacijskih koridorjih ter na ta način sprožajo socialno geografsko razslojevanje in fragmentacijo prostih površin. Pospešena motorizacija od 90-tih let prejšnjega stoletja dalje je odločilno prispevala $\mathrm{k}$ nastanku dodatnih pritiskov na obstoječi naselbinski sistem. Graditeljske aktivnosti v drobnih podeželskih naseljih brez ustreznih centralnih funkcij in infrastrukturne opremljenosti, deloma tudi izven prometno ustrezno opremljenih razvojnih osi, povzroča, da vedno manj ljudi razrešuje svoje mobilitetne potrebe s pomočjo varčnih načinov prometnih sredstev. S suburbanizacijo dolgoročno napreduje socialno razslojevanje in vodi v socialno geografsko polarizacijo med obmestji nasproti mestnim središčem. Ob tem pa kljub vsemu velja poudariti, da je ekonomska prosperiteta celokupnih aglomeracijskih območij neposredno odvisna od vitalnosti mest.

Vrednotenje naselbinskih tipov je pokazalo na napredujoči potek urbanizacije. Na približno tretjini slovenskega ozemlja, predvsem na ravninskih in dolinskih območjih pa se oblikuje sorazmerno močna decentralizirana koncentracija prebivalstva, čigar teritorij se na

\footnotetext{
9 gl. npr. Resolucijo o poglavitnih smotrih prostorskega razvoja SRS, 1970.

${ }^{10}$ ki si po časovnem vrstnem redu sledijo: Zakon o urejanju prostora (1984), Dolgoročni plan RS (1986), Zakon o urejanju prostora-ZUreP (2002), Strategija prostorskega razvoja-SPRS (2004) in Strategija razvoja Slovenije - SRS, ne upoštevajoč številnih sektorskih dokumentov.
} 
obrobju območij gospodarske in populacijske koncentracije ob ugodnih prometnih povezavah postopno širi proti s prometnega vidika odročnejšemu gričevju in hribovju. Ta diferenciacija je še vedno spontana. Dogaja se v območjih z zmogljivo infrastrukturo in še v primernem radiju ugodne dostopnosti do delovnih mest. Spremembe so najbolj izrazite v obmestjih največjih slovenskih mest oz. nastajajočih mestnih regij. Najvišje stopnje rasti (nad 105\%) beležijo obmestja v okolici Ljubljane, ob obalnih mestih, v Savinjski dolini, Spodnji Vipavski dolini, na osrednjem Gorenjskem in Dolenjskem.

Razlage o vzrokih dekoncentracijskih in disperzijskih procesov so različne. Splošno priznana ugotovitev je, da sodobni lokacijski faktorji podpirajo manj gosto pozidana naselbinska območja $\mathrm{z}$ ugodno dostopnostjo do prostih površin v sicer socialno heterogeni soseččini in s kakovostno infrastrukturno opremljenostjo. Ob razpravah o prihodnosti mest je navkljub velikemu številu interpretacij prodrlo spoznanje, da razvojno usmerjanje mestnih regij ni zgolj izraz trenutnih fizično-materialnih struktur in načina življenja, ampak gre za dinamičen organizem, ki je v stalni preobrazbi. Razsežnosti širjenja so odvisne od ekonomskih, socialnih in drugih činiteljev. V vsakem primeru pa lahko govorimo o procesu prerazporeditve razvojnih pritiskov (prebivalstva in delovnih mest) iz mest proti bližnjim obmestjem, čigar delež se v skupnem številu mestne regije povečuje.

Sodobna mesta so vse bolj nehierarhično razporejena in raznovrstna, kar je z vidika trajnostnega naselbinskega razvoja ugodno. Zato pa ima za uravnavanje sistemske reorganizacije mestnih regij največjo težo strategija mešane rabe površin, ki zagotavlja soobstoj dveh, interaktivnih usmeritev urejanja mest: zgoščevanje mestnega središča (mestna prenova in notranji razvoj) ob hkratnem zgoščevanju razpršene in suburbanizirane poselitvene strukture (zgostitve razpršene gradnje ob sočasnem prometnem in infrastrukturnem povezovanju. Poglavitna namera usmerjanja naselbinskega sistema s pomočjo mešane rabe površin je v uravnavanju dinamičnih procesov in obvladovanju kaotičnih teženj ter zmanjševanju entropije $\mathrm{z}$ ustvarjanjem vmesnih stabilnih stanj.

Na podlagi nakopičenih problemov, ki jih prinaša razpršitev ekonomskih aktivnosti pri prenosu razvojnih konceptov v prakso pa postajo vedno glasnejši tudi pozivi k oblikovanju projektno naravnanih instrumentov. To se dogaja zgolj zato, ker sodobni izzivi pospeševanja »navznoter naravnanega urbanega razvoja« niso več v popolnosti kos zastavljenim ciljem. Naraščajoče razseljevanje, potratna raba površin in povečana poraba energije tudi niso združljivi z načeli trajnostnega razvoja in izrabo naravnih virov. Geografija se je doslej aktivno odzivala na aktualne probleme predvsem z raziskovanjem pojavnih oblik in prikazom razvojnih dejavnikov, ki spodbujajo nove oblike urbanizacije. Ključna je tudi vloga v nakazovanju problemov in iskanju sodobnih metod in instrumentov pospeševanja atraktivnosti območij, pomembnih za bodoči naselbinski razvoj, ki jih spremljajo tudi nove pojmovne interpretacije kot npr.: urbani management in/ali urbani marketing. S pomočjo novih instrumentov pa je mogoče relativno abstraktno zasnovane cilje zapisane $\mathrm{v}$ razvojnih programih konkretizirati, razvojna hotenja nosilcev pa natančneje določiti in z okoljsko - uravnoteženega vidika tudi konsezualno umestiti v prostor. Visoka stopnja konkretizacije pa zahteva tudi podrobnejše informacije in boljšo informiranost prizadetih. Merilo uspešnosti je odvisno od stopnje prenosa v prakso in prav zato se zdi, da sta lahko urbani management/marketing ustrezna instrumenta za implementacijo ciljev prostorskega razvoja. 
Analiza nas je opozorila, da v številnih obmestjih že nastaja vzorec bolj uravnovešene porazdelitve delovnih mest in stanovanj ter raznolikih kombinacij dela in bivanja $\mathrm{v}$ kvalitetnejšem bivalnem okolju, kakršno nudi strnjena zazidava v mestu. Poglavitna naloga usmerjanja urbanizacije s pomočjo mešane rabe površin je predvsem v zavarovanju presledkov praznega oz. odprtega prostora. Z zgostitvami naselbinske in dejavnostne strukture se povečuje učinkovitost in preglednost urbanega sistema. Mešana raba površin zagotavlja še specializacijo posameznih zaposlitvenih središč v prostorski delitvi funkcij glede na pričakovane sinergetske učinke. Zato je eden izmed pomembnejših sodobnih nastavkov za bolj uravnotežen naselbinski razvoj, ker stremi k enakomernejšem prostorskem in socialno-ekonomskemu prepletanju med območji bivanja in dela. Usklajeno usmerjanje različnih dejavnosti na širšem območju mestnih regij lahko na ta način neposredno vpliva na racionalnejšo organizacijo prometnih tokov (= "oblikovanje območij kratkih poti"). Čim bolj raznovrstno je prostorsko prepletanje različnih ekonomskih in socialnih funkcij, tem krajše so dnevne poti zaposlenih in z njimi je povezan tudi življenjski slog tam prebivajočih prebivalcev.

S povečevanjem skrbi za prihodnost slovenskih obmestij se intenzivirajo tudi znanstvena proučevanja urbanizacije. Z njimi pa je povezano tudi zaznavno spreminjanje razumevanja tega prostorskega pojava: če so klasični razvojni modeli urbanega razvoja s priponko »sub« pomenili preusmeritev razvojnih teženj iz mestnih središč, potem novejši že naglašajo novo samobitnost obmestij ter njihovo lastno razvojno pot nasproti (staremu) mestnemu središču (Brake, 2001). Suburbanizacija potemtakem tudi v Sloveniji postavlja pred prostorske planerje kompleksne izzive, povezane $\mathrm{z}$ odnosi med mestnimi središči in pripadajočimi obmestji (npr. od povečanih prometnih obremenitev zaradi dnevne delovne migracije prebivalstva do zmanjševanja pomena mestnih središč...). Usmerjanje naselbinskih razvojnih procesov ima posebne zahteve pri optimiranju in pospeševanju lastnega notranjega razvoja. In zakaj je v tem primeru potreben nov instrument? Zato obstaja več razlogov za nadaljnje razvijanje metod in vsebin v urbanem managementu. Le nekaj primerov:

- Tradicionalne strukture obstoječega politično-administrativnega sistema tudi običajno niso pripravljene urbanih potencialov v polni meri podpirati. Pogosto je odsotna socialnotehnična kompetentnost in akceptanca, da bi se urbani akterji medsebojno povezali in $\mathrm{s}$ tem $\mathrm{z}$ aktivnejšim sodelovanjem spodbudili nov razvojni vzpon.

- Napet finančni položaj lokalnih skupnosti in omejene možnosti pridobivanja finančnih spodbud bodo zahtevale osredotočenje na izbrane (regionalne) razvojne projekte. To posledično povišuje stopnjo pripravljenosti (uskladitev interesov) za strateško odločanje (glede na optimizacijo urbanega razvoja), ki pri obstoječem politično-administrativnem sistemu ni vedno mogoča.

- Urbanizacijske specifičnosti se v Sloveniji zaradi njene mozaične pestrosti spreminjajo na majhne razdalje. Dosežena stopnja urbanizacije tudi ni istovetna $\mathrm{z}$ administrativnimi mejami in je pogosto odsev naravnih in drugih pogojev »neekonomske« narave (Ravbar, 1997). V tem primeru so razvojne poti območij s skupnimi naselbinskimi in razvojnimi problemi hitreje razrešljive mimo obstoječih institucionaliziranih (administrativnih) okvirov z iskanjem skupnih razvojnih ciljev, ukrepov in projektov na podlagi razvojnih, vendar neformalnih koalicij in instrumentov, kot jih ponuja urbani management. 
- Veljavni sistem prostorskega planiranja ne premore veliko instrumentov za implementacijo urejanja poselitve. Zato si ni mogoče zamisliti učinkovitega planiranja brez zakonskih, institucionalnih in sistemskih sprememb na tem področju, pa tudi ne brez sektorskega sodelovanja. Uresničevanje urbanega managementa rabe tal se nanaša na vzpostavljanje funkcionalnega, sonaravnega (uravnoteženega) in estetskega bivalnega prostora. Funkcionalnost se nanaša na ureditve, ki omogočajo gospodarski in socialni razvoj prebivalcev in družbene skupnosti, primerno gostoto zazidanosti ter infrastrukturno in komunalno opremljenost in ureditve, ki omogočajo zadovoljevanje temeljnih človekovih potreb. Sonaravnost pomeni varčno ravnanje z naravnimi viri (kot npr.naravni viri), kakor tudi zajezitev razpršene gradnje ter nekonfliktno in polifunkcionalno rabo površin. Estetsko bivalno okolje pomeni ureditve »po meri človeka«, preglednost in obvladljivost, ureditve v odnosu do naravno-geografskih razmer, topografije, lokalnega stavbarstva in funkciji poselitvenega sistema. Ti so: ponovna uporaba opuščenih površin, zgoščevanje, vzpostavljanje katastra "vrzeli" v zazidavi (posebej za stanovanjske površine), krmiljenje gradbenih širitev s pomočjo zaostrenih urbanističnih kriterijev, vodenje "ekokontov" v okvirih poostrenih določil kot npr. "kompenzacija” za poseg na nepozidane površine... Urbani management rabe tal se običajno osredotoča na iskanje "vrzeli" za stanovanjsko gradnjo, ponovno uporabo “opuščenih" površin, preobrazbo (prevrednotenje) proizvodnih površin s poudarkom na interkomunalnem sodelovanju in usposabljanje novih površin v navezavi na obstoječo (komunalno) opremo.

V prihodnostisebodonačini, oblikeobmestij, povezanihzizkoriščanjemin rabo infrastrukturnih omrežij še naprej razvijali. Težnje vodijo v smeri bolj koherentne, liberalne, učinkovite in okolju prijazne politike integralnega načrtovanja naselbinskega razvoja, komunikacij in prometnih sistemov.

\section{Viri in literatura}

Bergmann, E., Dosch, F., 2004: Von Siedlungsexpansion zum Flächenkreislauf. Trendwende zum haushälterischen Umgang. V: Planerin, Heft 01/2004, str. 5-8.

Brake, K., 2001: Neue Akzente der Suburbanisierung. Suburbaner Raum und Kernstadt: eigene Profile und neuer Verbund. Opladen, str. 15-26.

Herfert, G., 2002: Disurbanisierung und Reurbanisierung. Polarisierte Raumentwicklung in der ostdeutschen Schrumpfungslandschaft. V: Raumforschung und Raumordnung, Heft 5-6, str. 334-344.

Hesse, M., Kaltenbrunner, R., 2005: Zertrbild »Zersiedlung« - Anmerkungen zum Gebrauch und zur Dekonstruktion eines Begriffs. DISP 160 (1/2005), ETH Zürich, str. 16-22.

Kaltenbrunner, R., 2003: Scholle und Rand. Wohnen und Suburbanisierung - ein kaum steuerbarer Zusammenhang? V: Raumforschung und Raumordnung 5/2003, str. 319-333.

Matthiesen, U. (2002): An den Rändern der Hauptstadt. Opladen: Leske und Budrich.

Ravbar, M., 1992: Suburbanizacija v Sloveniji - odnosi, strukture in težnje v njenem razvoju. Doktorska disertacija, Univerza v Ljubljani, Filozofska fakulteta, Ljubljana, 325 str. 
Ravbar, M., 1997: Slovene Cities and Suburbs in Transformation (Slovenska mesta in njihova obmestja v preobrazbi). Geografski zbornik, št. XXXVII, Ljubljana, str. 64-109.

Ravbar, M., 2000: Vloga prostorskega planiranja v gospodarskem in regionalnem planiranju= Role of spatial planning in economic and regional development. Geographica Slovenica, 33/2, Ljubljana, 175-215 str.

Ravbar, M., 2002: Sodobne težnje v razvoju prebivalstva in delovnih mest - pot k sonaravnemu in decentraliziranemu usmerjanju poselitve v Sloveniji? IB- revija, št. 1, letnik XXXVI, Ljubljana, str. 12-41.

Ravbar, M., 2004: Razpotja naselbinskega omrežja v Sloveniji: težnje, razvojne dileme in možni scenariji. IB revija, letnik XXXVIII (2004), št. 4, Ljubljana, str: 41-52.

Ravbar, M., 2005: »Urban sprawl«: popačena slika (sub)urbanizacije v Sloveniji? Geografski vestnik 77-1, 2005, 27-36.

Ravbar, M., 2006: Slovensko podeželje na preizkušnji - kdo bo nadomestil kmetijstvo? Dela 25 , Slovenska politična geografija in podeželje na razpotju, Oddelek za geografijo na Filozofski fakulteti, str. 207-223.

Strategija prostorskega razvoja Slovenije ter Obrazložitev in utemeljitev Strategije prostorskega razvoja Slovenije: 2004: http://www.gov.si/upr/doc/SPRS_slo.pdf

Strategija razvoja Slovenije, 2005: http:/www.gov.si/umar/projekti/srs/Strategija razvoja Slovenije.pdf

Vrišer, I., 1969: Mala mesta v SR Sloveniji. Inštitut za geografijo Univerze v Ljubljani, Ljubljana, str. 37.

\title{
SOCIAL-GEOGRAPHIC TRANSFORMATION OF SETTLEMENT STRUCTURES - HOW TO DIRECT THE DEVELOPMENT?
}

\begin{abstract}
Summary
The growth of settlements in Slovenia has over the decades been associated with the growth of the outside borders of settlements beyond the historically and organically conditioned borders. Nowadays the greatest dynamics is not seen within cities but within the city-outskirts and rural settlements. The second characteristic of modern spatial settlement transformation is connected to the dominant and disperse build-up area with free-standing one-apartment houses, which instead of longtime wishes for decentralistic concentration of residential areas, deviates from the political goals and in proportion raises the costs of infrastructure. The described tendencies are most intense in the central part of Slovenia and in growing outskirts of all bigger cities, where the conditions of appropriate road (transport) accessibility are met.

The transformation of settlement structures is a chance for the development of methodological approaches in social geography, with which the possibility of studying the conditions and tendencies of settlement development would become a reality.

Although these processes are mostly modified within long-time periods, they are usually interpreted with current social-economic occasions. The transformation is followed on the economic as well as on the social-geographic level.
\end{abstract}


Because of the ever changing social laws the decades long suburbanization processes are getting a new quality, which is represented and modified in all urban geographical researches by city regions, twin cities in connection with the so called "postsuburbia". The transformation of area usage is seen through changed physiognomic and functional structures, which due to their mutual connection of cities with their outskirts give these areas a completely changed perspective in the modification of the urban system and its function.

In the future new types of suburbs linked to the usage of infrastructural nodes will continue to evolve. The tendencies lie within a more coherent, liberal, efficient and environment friendly politics of integral planning of settlement development, communications and transport systems. 